\title{
A Study on the Relationship of Middle School Students' Vocabulary Breadth Knowledge and Listening Comprehension
}

\section{Ting Yang}

School of Foreign Language, China West Normal University, Nanchong, Sichuan, China

\begin{abstract}
This study took 37 junior students who were from an institution of Nanchong as research objects. In this study, SPSS was used for making quantitative analysis on the collected data, intending to explore the relationship of middle school students' vocabulary breadth knowledge and listening comprehension. The results show: (1) The current vocabulary breadth level of middle school students accounted for $80.86 \%$ of the overall requirements, and their listening comprehension level reached $85.87 \%$ of the general requirements, both of which were in an upper level; (2) Students' vocabulary breadth and listening comprehension level in different gender didn't have a significant difference; (3) There was a significant positive correlation between middle school students' vocabulary breadth and listening comprehension. This study has some guiding significance on the listening teaching of primary and secondary schools.
\end{abstract}

Keywords: middle school students; vocabulary knowledge; vocabulary breadth; listening comprehension

\section{Introduction}

Vocabulary is to language just as what bricks and stones are to buildings. It plays a very important role in foreign language learning. Wilkins (1972) believed that without grammar, we can hardly express ourselves, and without vocabulary, we can be unable to express ourselves. Lacking vocabulary breadth knowledge will inevitably affect the understanding of language. However, as the English curriculum standard clearly pointed out, foreign language teaching must cultivate students' listening, speaking, reading, writing and seeing ability. And as one of the most important language skills, listening plays an important role in the process of language learning. It is worth studying that to what extent listening comprehension ability is influenced by students' knowledge of vocabulary breadth. Therefore, this study attempts to explore the relationship between the two by conducting descriptive statistics, independent sample t-test and correlation analysis on students' listening performance and vocabulary breadth through SPSS.

\section{Related Research}

The two dimensions of lexical knowledge, lexical breadth and lexical depth, have been widely accepted and used by people (Qian,1999). Vocabulary breadth refers to learners' superficial grasp on the vocabulary meaning. That is the "quantity" of vocabulary (Anderson\&Freebody,1981). Vocabulary depth refers to the clear grasp of the deep meaning, fixed collocation, grammar and other rules of a vocabulary, namely the "quality" of vocabulary (Zhang Xiaodong, 2011). Foreign researches in this field started earlier. There are a lot of literature studies. Although the studies differ in the subjects, methods and strategies, they all reach a consistent conclusion that there is a significant positive correlation 
between vocabulary breadth and listening comprehension (Mecartty, Nation, Bonk and others). In addition, many domestic experts and scholars (Zhang Xiaodong, Wang Tongshun and Lin Wenjie) have also carried out relevant studies on this field and reached similar conclusions.

Although previous researches have entered a mature stage, there are still some aspects can be further improved. In the existing researches, the research objects are not comprehensive enough, most of them are college and high school students. The primary and secondary school students are rarely studied. And there is no research on students in training institutions. In view of this situation, this study takes the students of a training institution in Nanchong city as the research objects, in order to verify the universality of the research conclusions to a certain extent, hoping to provide some guidance for listening teaching.

\section{Research Design}

\subsection{Research questions}

The research questions of this study are as follows:

(1) What is the current vocabulary breadth level of junior high school students? And what is their listening comprehension level?

(2) Are there any gender difference in their vocabulary breadth and listening comprehension level?

(3) What is the correlation between these two aspects?

\subsection{Research subjects}

This study took 37 junior three students of a training institution in Nanchong city as research objects, including 17 male students and 20 female students. Students in this class came from different junior high schools in Nanchong. They have been learning English since Grade 3 in primary school. So far, they had about 7 years of English learning experience, and had accumulated a large amount of vocabulary knowledge and relatively mature listening comprehension skills.

\subsection{Research instruments}

The research instruments used in this study are as follows:

\subsubsection{Vocabulary breadth test paper}

The VST (Vocabulary Size Test) scale, which was proposed by the famous scholars Nation \& Beglar, was used as a reference. On this basis, the test paper also made relevant adaptation based on some required words for the high school entrance examination in Compulsory Education Curriculum Standards (2011 edition), which ensured the typicality and representativeness of selected words. The questions were presented in the form of 100 single choice questions, and students were asked to choose the one that best matches the meaning of the words given in the four Chinese language choices. One point for each question, a total of 100 points, mainly focused on the mastered vocabulary level of the respondents. The test volume had been tested many times and had a high internal reliability.

\subsubsection{Listening comprehension test paper}

The listening comprehension test paper used in this study was an English test paper for the high school entrance examination. The high school entrance examination, which was recognized as a standardized test in China, was not only a major indicator to measure whether a student has the required level for graduation from junior high school, but also a prerequisite for high school entrance. The exam was 30 points, 25 questions in total, one point for each of the first 20 questions and two points for each of the last 5 questions. After being discussed so many times by experts, scholars and proposition groups, this test paper had good reliability and validity, which can objectively, accurately and comprehensively evaluate respondents' English listening ability. 


\subsection{Research processes}

The collection of relevant data took place on the evening of 16 November, 2019. Before the test, I communicated with students effectively. Besides, I emphasized the significance of the research, the importance of real data, and told them that they were conducting relevant research, in which everything should be true. In the process, students were required to complete the test in class. The breadth test was 20 minutes, and the listening test was 30 minutes. The test was supervised by the teacher, the assistant teacher and the author. During the test, students showed high enthusiasm, high participation, and treated it seriously. All of the data were real and effective.

\section{Research Results}

\subsection{Basic level of vocabulary and listening}

From table 1, we can see that in the vocabulary breadth knowledge test, the minimum score was 55, and the maximum score was 96. The standard deviation was 9.681, which meant there was a huge internal difference in surveyed students' vocabulary breadth knowledge level. Meanwhile, the average score was 80.86, which meant their average vocabulary breadth knowledge reached $80.86 \%$ of the general requirements, mastering more than four fifths of the required vocabulary in the junior middle school stage.

In the listening comprehension test with a full score of 30 , the lowest score was 20 , and the highest score was 29 . The overall standard deviation was 2.153 , indicating that the listening comprehension difference among surveyed students was small. The average score was 25.76 , reaching 85.87 percent of the overall requirements, which was above the average level with a good performance.

Table 1. Descriptive statistics of middle school students' vocabulary breadth knowledge and listening comprehension $(\mathrm{N}=37)$

\begin{tabular}{|c|c|c|c|c|c|}
\hline & N & $\begin{array}{c}\text { Mini } \\
\text { mum }\end{array}$ & Maximum & Mean & $\begin{array}{c}\text { Std. } \\
\text { Deviation }\end{array}$ \\
\hline Vocabulary breadth score & 37 & 55 & 96 & 80.86 & 25.76 \\
\hline Valid N (listwise) & 37 & & & & \\
\hline $\begin{array}{c}\text { Listening Comprehension } \\
\text { Score }\end{array}$ & 37 & 20 & 29 & 25.76 & 2.153 \\
\hline Valid N (listwise) & 37 & & & & \\
\hline
\end{tabular}

4.2 Analysis of differences in students' vocabulary knowledge and listening comprehension in different genders

As can be seen from table 2, a total of 20 male students were surveyed, with an average vocabulary breadth knowledge of 80.55 , and 17 female students, and an average vocabulary breadth knowledge of 81.24 . The average vocabulary breadth knowledge level of female students was slightly higher than that of male students, with a gap of 0.69. The standard deviations of male and female students in this respect were 8.982 and 10.715 respectively, indicating that the internal differences in vocabulary breadth and knowledge level of female students surveyed were slightly larger than those of male students.

In the results of independent sample T-test, the homogeneity variance test showed that the F-value was 0.937 , while the Sig-value was 0.340 , which was much larger than 0.05 . Therefore, the variance of vocabulary breadth and knowledge level of students in different genders was homogeneous. Among them, the value of Sig. (2-tailed) was 0.834 , indicating that there was no significant difference in different genders students' vocabulary knowledge.

In this study, the independent sample T-test was used again to test and analyze their listening comprehension. 20 male 
students were surveyed with an average listening comprehension of 26.00 , while 17 female students were surveyed with an average listening comprehension of 25.55. The average listening comprehension score of female students was lower than that of male students with 0.45 points. The standard deviations of male and female students' listening comprehension were 2.449 and 1.905 respectively, indicating that the internal difference of male students' listening comprehension was slightly larger than that of female students.

In the independent sample T-test, the homogeneity variance F-value was 0.152 , and the Sig-value was 0.699 , which was also much larger than 0.05 . So it was the homogeneity variance. And the Sig. (2-tailed) value was 0.534 , indicating that there was no significant difference in different genders students' listening comprehension.

Table 2. Descriptive statistics of students' vocabulary breadth knowledge and listening comprehension ( $\mathrm{N}=37)$

\begin{tabular}{|c|c|c|c|c|c|}
\hline \multicolumn{2}{|c|}{ Gender } & N & Mean & $\begin{array}{c}\text { Std. } \\
\text { Deviation }\end{array}$ & $\begin{array}{c}\text { Std. Error } \\
\text { Mean }\end{array}$ \\
\hline $\begin{array}{c}\text { Vocabulary } \\
\text { breadth score }\end{array}$ & Male & 20 & 80.55 & 8.982 & 2.009 \\
\cline { 2 - 6 } & Female & 17 & 81.24 & 10.715 & 2.599 \\
\hline $\begin{array}{c}\text { Listening } \\
\text { comprehension } \\
\text { score }\end{array}$ & Male & 20 & 25.55 & 1.905 & .426 \\
\cline { 2 - 6 } & Female & 17 & 26.00 & 2.449 & .594 \\
\hline
\end{tabular}

Table 3. Independent samples test of students' vocabulary breadth knowledge and listening comprehension ( $\mathrm{N}=37)$

\begin{tabular}{|c|c|c|c|c|c|c|c|c|c|}
\hline & \multicolumn{2}{|c|}{$\begin{array}{l}\text { Levene's Test } \\
\text { for Equality } \\
\text { of Variance }\end{array}$} & \multicolumn{7}{|c|}{ T-test for Equality of Variance } \\
\hline & \multirow[t]{2}{*}{$\mathbf{F}$} & \multirow[t]{2}{*}{ Sig. } & \multirow[t]{2}{*}{$\mathbf{t}$} & \multirow[t]{2}{*}{ df } & \multirow[t]{2}{*}{$\begin{array}{l}\text { Sig. (2- } \\
\text { tailed) }\end{array}$} & \multirow[t]{2}{*}{$\begin{array}{c}\text { Mean } \\
\text { Difference }\end{array}$} & \multirow[t]{2}{*}{$\begin{array}{l}\text { Std. Error } \\
\text { Difference }\end{array}$} & \multicolumn{2}{|c|}{$\begin{array}{l}95 \% \\
\text { Confidence } \\
\text { Interval of the } \\
\text { Difference } \\
\end{array}$} \\
\hline & & & & & & & & Lower & Upper \\
\hline Vocabulary breadth test score & .937 & .340 & -.212 & 35 & .834 & -.685 & 3.237 & -7.257 & 5.886 \\
\hline Equal variances assumed & & & -.209 & 31.3 & .836 & -.685 & 3.285 & -7.381 & 6.010 \\
\hline Equal variances not assumed & & & & 91 & & & & & \\
\hline Listening comprehension score & .152 & .699 & -.628 & 35 & .534 & -.450 & .716 & -1.904 & 1.004 \\
\hline Equal variances assumed & & & -.616 & 30.0 & .543 & -.450 & .731 & -1.943 & 1.043 \\
\hline Equal variances not assumed & & & & 02 & & & & & \\
\hline
\end{tabular}

4.3 The correlation between students' vocabulary breadth knowledge and listening comprehension

In this study, junior high school students' vocabulary breadth and listening comprehension were taken as dimensions and Pearson correlation was used to analyze the correlation between them. As shown in table 4, the correlation coefficient between students' vocabulary breadth and listening comprehension was 0.843 . In statistics, generally the absolute value between 0.20 and 0.40 is called a low correlation. $0.40-0.70$ is a real correlation, which is also known as a moderate correlation. That is a relatively significant correlation. And $0.70-0.90$ is a high correlation, which is a significant correlation (Qin Xiaoqing, 2003). It was concluded that the vocabulary breadth knowledge of junior high school students was positively correlated with the listening comprehension. It indicated that students' vocabulary breadth and knowledge 
level can directly reflect students' listening comprehension level to some extent.

Table 4. Test of correlation between students' vocabulary breadth knowledge and listening comprehension (N=37)

\begin{tabular}{|c|c|c|c|}
\hline \multicolumn{2}{|c|}{} & $\begin{array}{c}\text { Vocabulary breadth } \\
\text { score }\end{array}$ & $\begin{array}{c}\text { Listening } \\
\text { comprehension score }\end{array}$ \\
\hline $\begin{array}{c}\text { Vocabulary breadth } \\
\text { score }\end{array}$ & Pearson Correlation & 1 & .843 \\
\cline { 2 - 4 } & Sig.(2-tailed) & 37 & .000 \\
\cline { 2 - 4 } score & Number of cases & & 37 \\
\hline \multirow{2}{*}{\begin{tabular}{c} 
Listening comprehension \\
\cline { 2 - 4 }
\end{tabular}} & Pearson Correlation & .843 & 1 \\
\cline { 2 - 4 } & Sig(2-tailed) & .000 & 37 \\
\cline { 2 - 4 } & Number of cases & 37 & \\
\hline
\end{tabular}

\section{Discussion}

The results showed that the surveyed students' vocabulary breadth level and listening comprehension level were both relatively optimistic. In the vocabulary breadth test with a full score of 100 and listening comprehension test with a full score of 30 , students both achieved an accuracy rate of more than $80 \%$. Students' mean values of vocabulary breadth knowledge and listening comprehension were 80.86 and 25.76 respectively, both of them were above the average level. This is different from the current domestic research results. For example, in the research results of Liu Quan (2019), 136 people obtained an average score of 73.34 in vocabulary breadth knowledge and 24.43 in listening comprehension. This may be because this study was based on the class with a good performance in a training institution. Students' overall learning situation was better, which may affect the research results to some extent.

However, as shown by the data, students' average score in the vocabulary breadth test was 80.86 , and the minimum score was 55. The highest score was 96, and the student who got it was a girl, and the second score was 95, and the student who got it was also a girl. The third score was 94, with a boy got this grade. According to the test results, girls may be better at accumulating vocabulary than boys, but their performance in vocabulary breadth was far from satisfactory. Several students lost score for misunderstanding the Chinese meaning of "cold" and "tourist". Indirectly, it reflected that students cannot distinguish the meaning of some words well in the vocabulary learning process, and it was common for them to understand it equivocally. Therefore, English teaching should actively strengthen vocabulary teaching, so that students' vocabulary can be expanded. But, meanwhile, the understanding of words meaning, part of speech distinction should also be strengthened.

The average score of students in listening comprehension was 25.76, and the lowest score was 20. Their highest score was 29. Students who did not get full marks still need to make a breakthrough. In addition, students' listening test papers showed that students still had the following problems in listening: (1) They can't judge the vocabulary quickly based on the audio; (2) Fast transition was not possible when encountering new words. Therefore, teachers should pay attention to the following aspects in their teaching: first, students' phonetic ability should be developed, to reduce the situation that students can't recognize the sounds of words. Secondly, the teaching of listening skills should be strengthened to guide students to have a quick understanding of new words and make accurate choices in the listening process by guessing words, through which students' performance in listening may be improved. 


\section{Conclusions}

This study investigated junior high school students from two dimensions, the vocabulary breadth and listening comprehension. And the results showed that: (1) Junior high school students' current vocabulary breadth knowledge accounted for $80.86 \%$ of the overall requirements, and their listening comprehension level reached $85.87 \%$ of the overall requirements, both of them were above the average level; (2) There was no significant difference among students of different genders in both tests; (3) There was a significant positive correlation between junior high school students' vocabulary breadth and listening comprehension.

English knowledge is divided into phonetic, vocabulary, grammar, discourse and pragmatic knowledge. Vocabulary knowledge plays a fundamental role in the process of language learning and is also the most important part that students need to master in the learning process. The results of this study indicate that learners' accumulation of vocabulary knowledge can predict their listening comprehension performance to a certain extent. Therefore, English teachers should help students establish a correct vocabulary concept in the teaching process, and guide students to learn more vocabulary actively. Besides, vocabulary teaching should be conducted through various channels. Meanwhile, the methods of vocabulary teaching and listening skills should be improved reasonably. Vocabulary and listening complement each other, so that teachers must pay attention to the relevance of the two aspects in teaching process.

Admittedly, although based on empirical evidence, this study had some beneficial implications for vocabulary and listening teaching, there were still some limitations. First, the sample was only 37 , which would be more representative if it was larger. Second, due to the constraints of time and some other objective factors, only one set of listening test paper was used in this study. The evaluation was a little absolute, which could not well reflect students' real listening level. Third, due to the lack of time, students could not be interviewed, so the data lacked qualitative analysis, and the combination of qualitative and quantitative analysis could not be achieved. Future research can be conducted by avoiding the above limitations for further objective exploration.

\section{Conflicts of Interest}

The author declares no conflicts of interest regarding the publication of this paper.

\section{References}

[1] Qian D. (1999). Assessing the Roles of Depth and Breadth of Vocabulary Knowledge in Reading Comprehension. The Canadian Modern Language Review, (2): 283-307.

[2] Anderson, Freebody (1981). Vocabulary Language in J.T. Guthrie. Comprehension and Teaching. International Reading Association, Newark.

[3] Zhang X.D. (2011). A Research on the Relationship between Vocabulary Knowledge and Second Language Listening Comprehension. Language world, (2): 36-42.

[4] Nation I.S.P., Beglar. (2007). A Vocabulary Size Test. The Language Teacher, (31): 9-13.

[5] Liu Q. (2019). A Study on the Relationship between Junior Middle School Students' English Vocabulary Knowledge and Listening Comprehension. Huaibei Normal University.

[6] Qin X.Q. (2003). Quantitative Data Analysis in Foreign Language Teaching Research. Huazhong University of Science and Technology Press, Wuhan.

[7] Zhao W., Chen Y.J., Lu W.Z. (2014). A Comparative Study on Vocabulary Acquisition in Chinese and Foreign Languages in Recent Ten Years. Language world, (163): 39-46.

[8] Lv C.H. (2004). The Relationship between Vocabulary and Comprehensive Language Ability and Depth Knowledge of Vocabulary. Foreign Language Teaching and Research, (02): 116-123. 
[9] Wang M.L. (2015). Analysis of Hearing Impairment in Middle School and Research on Teaching Strategies. Education Science \& Culture Magazine, (4): 115.

[10] Bai L.M. (2002). The Role of the Breadth and Depth of English Vocabulary Knowledge in Reading Comprehension. Northwest Normal University, Lanzhou.

[11] Tao T.T. (2011). Research on the Influence of Foreign Language Learners' Vocabulary Knowledge on Listening Comprehension. Suzhou University. 